\title{
Institution of higher education transformation and society's response to distance learning during the Covid 19 pandemic
}

\author{
Olga Yarmak $^{1, *}$, Tatyana Shkaiderova ${ }^{1}$, Ekaterina Strashko ${ }^{1}$, Maria Bolshakova ${ }^{1}$, and \\ Lyudmila Garas ${ }^{1}$ \\ ${ }^{1}$ Sevastopol State University, 33, Universitetskaya St., Sevastopol
}

\begin{abstract}
The article analyzes the transformation of the institution of higher education and traditional education during the epidemiological crisis, due to which distance learning was introduced in universities on a federal scale. The authors focus not only on the effect of the introduction of online technologies into the higher education system, but emphasize the uniqueness of the situation in the context of the need to use these tools in order to minimize social communications when it comes to the viral threat. The authors' use of cybermetric analysis, big data mining, and media monitoring using the Medialogia analysis system allowed to analyze the information agenda in the federal media space, to determine how the traditional education changed in the context of the Covid 19 pandemic. The specificity of perception of distance learning by Russian society is noted. It was revealed through analysis of the media space concerning the activities of the Ministry of Science and Higher Education of the Russian Federation from February to June 2020. The article emphasizes that the discussion on digitalization of the educational process will continue. The authors draw attention to the fact that joint efforts of the state and civil society can contribute to the development of an adequate model of higher education, based on the convergence of traditional and digital educational forms, taking into account the interests of all the participants in the higher educational process.
\end{abstract}

\section{Introduction}

The communication revolution and the formation of the information society, being the key processes of our time, lead to changes in all spheres of society and cause the transformation of "familiar" institutions and established practices. The gradual development of social transformations determines the work of adaptation mechanisms that adapt emerging innovations to changing conditions. However, given the nonlinearity and increased entropy of modern processes, the emergence of global force majeure circumstances, such as the Covid 19 epidemic, when society is exposed to risks and social upheavals, these mechanisms are

\footnotetext{
*Corresponding author: olga_yarmak@inbox.ru
} 
not able to respond quickly, which is fraught with unpredictable consequences and requires deep scientific reflection.

The expert group, initiated by the Ministry of Science and Higher Education of the Russian Federation, presented one of the first analytical materials about the life of the country's universities in the context of the pandemic in the report "Lessons from the stress test". Universities during the pandemic and after it ", which presents materials on the functioning of the educational process, the content and technologies of education, infrastructure and management system in universities, and the analysis of measures taken in Russian education in an international context [1-5]. One of the conclusions of the report is that during the time of distance work, the demand for digital didactics, the creation of a set of methods and rules for teaching online, contributing to the disclosure of the potential of digital technologies and direct interaction of teachers and students, has become urgent.

\section{Materials and methods}

The explosive development of information and communication technologies has driven the evolution of the digital landscape and fueled the emergence of new research tools to analyze big data. The research methodology was based on the cybermetric analysis and big data mining, the media space monitoring using the social network analysis system "Medialogia" created by the developer of an automatic system for monitoring and analyzing media and social media in real time, which is currently the leader of the Russian federal media space.

The data obtained with the use of such automated systems can be interpreted as "big sociological data" that allow analyzing in social media and mass media a person's reaction to crisis phenomena, his behavioral attitudes on the Internet. We believe that big sociological data can be considered not as a technical phenomenon, but as a social one, allowing to analyze information flows, social interaction in the field of communications, which forms models of awareness of crisis situations in society. Despite a number of advantages of such data, it is necessary to note their disadvantages: the insufficient reliability of the personal data of the Internet audience, its limitedness - the researcher has to work only with that part of the audience that is represented on the network, and the transparency of building the mechanism of the data upload algorithm.

The "Medialogia" monitoring system has developed its own Media Index - an indicator that allows you to qualitatively analyze the effectiveness of PR services efforts (calculated automatically using linguistic analysis technologies according to the methodology developed by Medialogia), and includes three main components: the citation index, which takes into account the number of links on media materials; indicator of positive and negative content a qualitative criterion of the nature of the mention of a particular object in the message; and visibility of a message is a cumulative parameter that takes into account the "advertising equivalent" of a publication [6-7].

The research was carried out using a comparative method, which made it possible to study the process of transformation of higher education in the process of transition to distance learning in the context of an epidemiological crisis in Russian society.

\subsection{Description of the empirical research model}

Characteristics of the analyzed content: 24556 messages (totally all the analyzed media categories) with a depth of unload from February 1, 2020 to June 30, 2020 (monthly for five months) and coverage of all media categories (newspapers, magazines, Internet, news agencies, radio and TV). Media monitoring was carried out using "Medialogia", the monitoring service for the analysis of social networks, by the search query "Ministry of Science and Higher Education" in a monthly monitoring mode. The obtained data reflect the 
analysis of the Russian federal media space as a whole and by region on topics related to the activities of the Ministry of Science and Higher Education.

The purpose of the research case was to identify changes in the information agenda in the federal media space and identify trends in the transformation of habitual educational practices, and perception of distance learning by analyzing information about the activities of the Ministry of Science and Higher Education from February 2020 to June 2020.

The research objectives were:

- analysis of the media field by the search object with the dynamics of media coverage, a description of information peaks, and the specifics of media coverage;

- determination of the role of references and their dynamics for the analyzed search object;

- description of genres and headings of references;

- analysis of the tonality of the revealed content;

- a description of the coverage of the process of university distance learning in the federal media space with the dynamics and specifics of coverage in the media.

\section{Discussion}

The Covid 19 pandemic and unprecedented precautions including the introduction of a social distancing regime in order to reduce interpersonal contacts and, therefore, minimize the transmission of the virus in close social contacts offline, raised the issues of social interaction, stability of the social system, and defining the boundaries of social safety in a new way. Expressing in the light of the approach of sociologists I. Wallerstein and E. Toffler: with the advent of the "end of the familiar world", perceived as an immanently inherent "background of our life", "the familiar meaning of being is receding into the past and the world" becomes "hostile and incomprehensible," humanity falls into "futuroshock", that is, into a previously unknown psychological state characterized by a loss of a sense of reality and the ability to orientate in life [8-10].

Having affected almost all spheres of public life, the coronavirus pandemic has made essential adjustments to the education system, leading to the complete closure of educational institutions, causing the forced transfer of the educational process to digital and distance learning at all levels - from secondary to higher education.

It should be noted that in the context of the penetration of online technologies and mobile services into social practices, discussions on the introduction of digital technologies into the educational process have been going on for a long time. However, at the time of the start of the pandemic of the new coronavirus infection - March 2020 - no consensus could be reached on this discussion. Forced social distancing determined the loss of the established boundaries of the personality, increased the inclusion of a person in the virtualized world, which led to an increase in the atomization of Russian society, launched an identity crisis, and the loss of familiar landmarks in the social space.

Based on the reflections of the culturologist Stuart Hall, identity, setting the basic meanings, has a sufficient degree of mobility, that is, it always remains incomplete. It is "in progress" and is continuously "formed" [2]. In the changing dynamics of social interactions, the content of identity is the result of discourse, which can be represented as a certain sequence of statements capable of influencing the models of a person's subjective experience, his internal representation of the world, beliefs and behavior [4]. That is, the virtualization of communication is able to change the boundaries, in particular, "friend-foe", formed by media intentions. If the concept of " foe " used to be very distant, with the outbreak of the coronavirus epidemic, a close person (fellow student, colleague, etc.), potentially infected with the virus, can be perceived as a threat, which leads to the transition of the category "friend" into the concept of " foe " and "an accomplice of the epidemic", increasing fear, which is used as a mechanism of social domination [9]. 
According to security researchers Barry Buzan and Ole Weaver, social security, which is part of the concept of security along with military, political, economic and environmental ones, reflects the ability of society to maintain its vital character in changing conditions, in a situation of possible or real threats, when society is threatened with loss of identity [11]. That is, social security extends to society's responses to real or perceived threats to the individual and social cohesion.

Higher education for students is not only an opportunity for stratification growth, but also a kind of social tradition. The expression "go to university", which is common in the student environment, means for a young person an independent life and study, the formation of new social ties, the acquisition of social experience. Therefore, the limitation of social contacts due to distancing can cause not only social disunity and isolation, but also trigger the collapse of social interactions [1]. Traditional face-to-face learning during the coronavirus pandemic began to be perceived by society as a potential threat requiring certain countermeasures, namely the introduction of "safe" distance learning.

\section{Results}

The dynamics of the media coverage of distance learning reflected the critical growth of online queries for the search object "Ministry of Science and Higher Education" in March 2020: interest in the activities of the ministry grew almost 4 times compared to February. In April and May, there was an even level of online interest in the work of the Ministry of Science, and in June it already declined (Fig. 1).

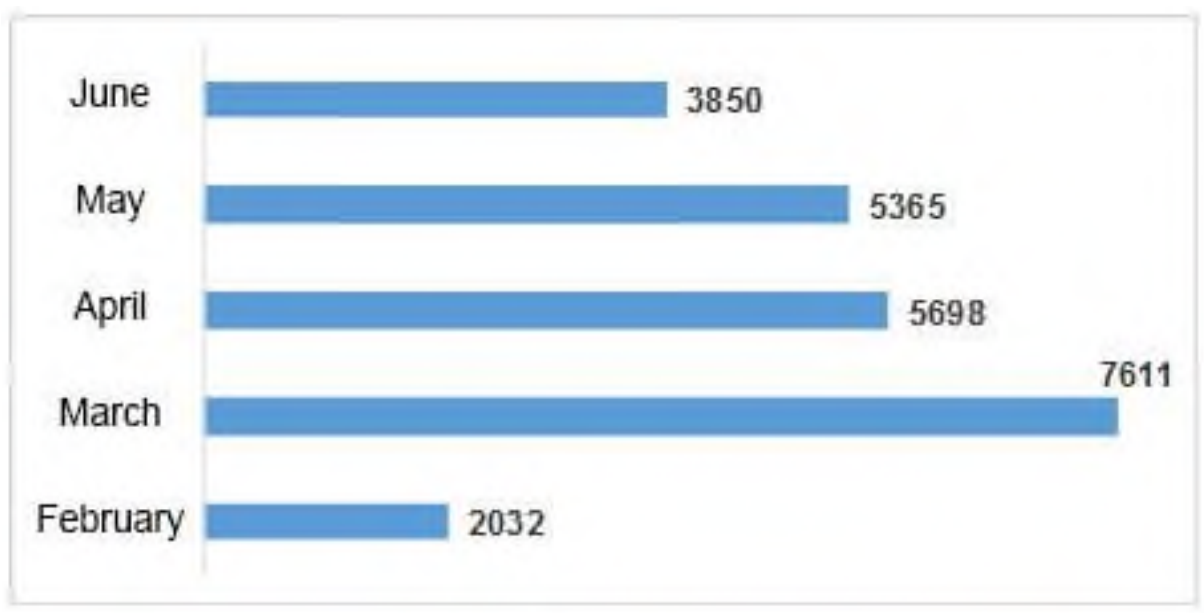

Fig. 1. Media dynamics of the search object "Ministry of Science and Higher Education" for the period February-June 2020 (in units).

Based on the research goals, the entire period under research was differentiated into three parts: the pre-distance period (February - March 16, 2020), the introduction of distance learning (March 16 - April 5, 2020) and the distance learning itself (April 06 - June 30, 2020) .). But if we look at the graphs of media dynamics not by months, but present them as a whole, we can note several trends: first, there is a classic functioning of the media space with peaks and falls in February, May and June; second, the March transition to the distance learning became the only monthly peak and eclipsed the entire space of the month; thirdly, the April media field, which should be viewed as a continuation of the March introduction of distance learning (after March 16), reflects the synchronicity of peaks and falls, characterizing its normal functioning (Fig. 2). 


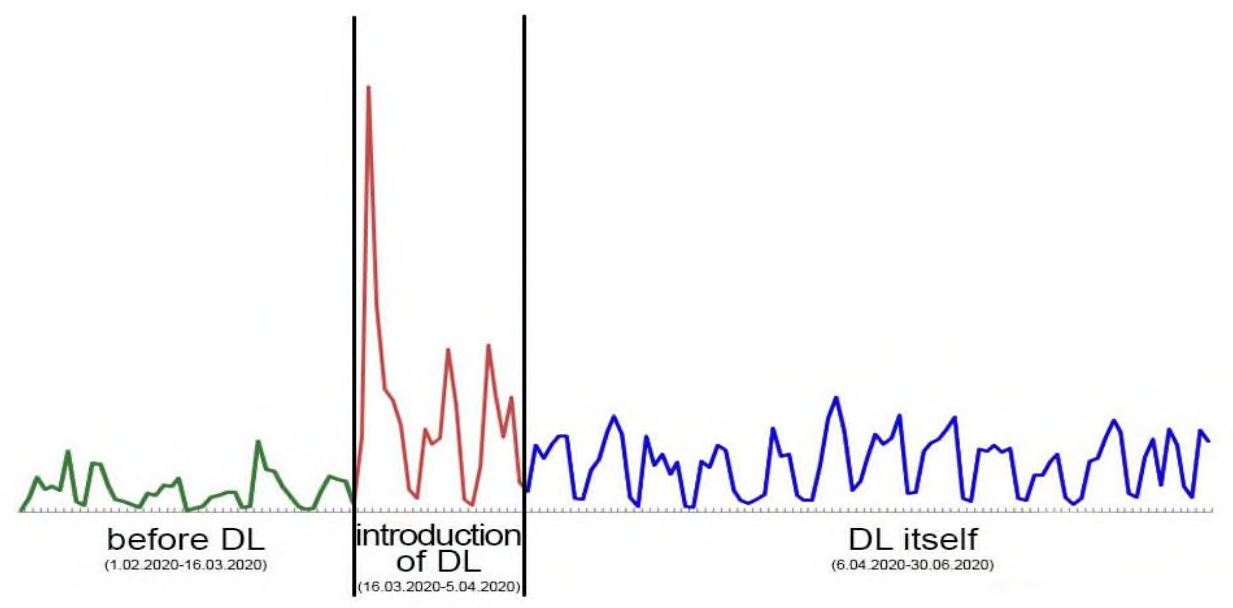

Fig. 2. Dynamics of media activity of the search object "Ministry of Science and Higher Education" in the pre-distance learning period, the period of introduction of the distance learning (DL), the period of the distance learning itself.

The dynamics of the media activity of the search object "Ministry of Science and Higher Education" in the three observed periods reflects both the peaks of references to the Ministry of Science and Higher Education in the media and media tracks formed during these periods.

The top topics of February reproduced the daily work of the ministry: the opening of the Mendeleev Center children's technopark by S.S. Sobyanin, the awarding ceremony "For loyalty to science", the opening of the winter school of VTB Bank and the Higher School of Economics in finance and credit, and the "Victory Dictation". As it was already noted, in March, the greatest media activity occurred in the middle of the month with the introduction of distance learning and was marked by such news-worthy subjects as "recommendation to universities to switch to distance learning from March 16, 2020", "days off for universities and research organizations until April 32020 ","distance thesis defence","remote submission of documents by applicants." The news on March 16 about the transition to distance learning in universities found a response in its peak value - 1512 messages out of their total number (7611) for the entire month, which amounted to $20 \%$ of the monthly information flow about the distance learning. The April media pics fell on the beginning of the month: from April 1 to April 3, references to the Ministry of Science and Higher Education reached a maximum for the entire month, reaching more than 400, and related to the discussion of the Ministry's recommendations to resume the educational process at universities distantly from April 6 . The May period, attributed by the authors to the period of the distance learning itself, began to return the media agenda to the pre-distant period - the coverage of current, non-crisis, events (unified national exam in a distance format, a meeting on the current situation in the education system, lack of plans to postpone the beginning of the academic year, organization of graduation and entrance, additional entrance examinations, all-Russian graduation ceremony).

June's top news subjects have finally returned the media agenda to a pre-distant period. It still contains the topic of distance learning and the impact of the epidemic on the educational process - changing the rules of admission in connection with the pandemic, receiving additional points for volunteering by applicants, organizing consulting assistance for foreign students, organizing online consultations on preparing for the Unified State Exam, organizing an all-Russian online graduation ceremony; but also current events reflecting the daily work of the ministry - the issuance of housing certificates to young scientists, the emergence of a new program to increase the global competitiveness of universities, the launch of the Pskov 
State University scientific project dedicated to the 75th anniversary of the Victory, the project "Small Motherland in the Mirror of Oral History of the Great Patriotic War", completion of applications accepting for participation in the "Big Change" competition, organizing expeditions for students to study monuments of Russian memorial culture, Forbes rating of the 100 best Russian universities, student (maternal) capital.

It is expected that the dominant problematic of the distance learning period turned out to be topics related to the Unified State Exam, correlating with the mode of operation of admissions committees of universities (admission rules, entrance tests, state-funded places). But at the end of the distance semester in June, two information streams occurred: the first one, associated with the introduction of digital technologies and anti-virus measures - the launch of admission campaigns distantly, admission of documents to universities online, the USE with the requirements of social distancing, permission to hold mass events taking into account the epidemic situation, and the second one, focusing on the current agenda and returning to the themes of the pre-distant period: coverage of problem areas of relations between teachers and the administration, the "Big Change" competition, the academic leadership program, the Forbes university ranking.

Discussion of the work of the Ministry of Science and Higher Education from February to May took place mainly in the regional media field and only in June the agenda began to dominate in the federal space. The federal news agencies TASS, RIA Novosti, IA Regnum became the leaders of active online media for the entire study period. The second most active group was made up of regional online media, going ahead of the number of messages from federal news agencies: the Moscow City News Agency, the Evening Moscow city news portal, Moscow 24, Siberian news Taiga.info, Tyumenskaya Nedelya news agency, Yakutskoe-Sakha informational YASIA agency, AmurMedia news agency (Table 1).

Table 1. Media platforms by Media Index on the search object "Ministry of Science and Higher Education"for the period February-June 2020 (in units).

\begin{tabular}{|l|c|c|c|}
\hline $\begin{array}{c}\text { period / } \\
\text { media level }\end{array}$ & federal & regional & total \\
\hline February & 619 & 1413 & 2032 \\
\hline March & 2147 & 5464 & 7611 \\
\hline April & 1796 & 3902 & 5698 \\
\hline May & 1577 & 3788 & 5365 \\
\hline June & 490 & 289 & 779 \\
\hline
\end{tabular}

The geography of references to the analyzed media space for the search object "Ministry of Science and Higher Education" reflected, on the one hand, its logical presence in regions with a large number of universities (Moscow, St. Petersburg, Republic of Tatarstan, Republic of Crimea, Irkutsk, Omsk, Sverdlovsk and Novosibirsk regions, Altai Territory, Krasnodar Territory), on the other hand, it indicated the leadership of Moscow, which is associated with the geographical location of the main federal media in the capital.

Analysis of the ratio of publications by role showed that the growth in the dominance of references to the ministry is observed in the active distant learning period (March and April), while February and June broadcast the traditional media state (Fig. 3). 


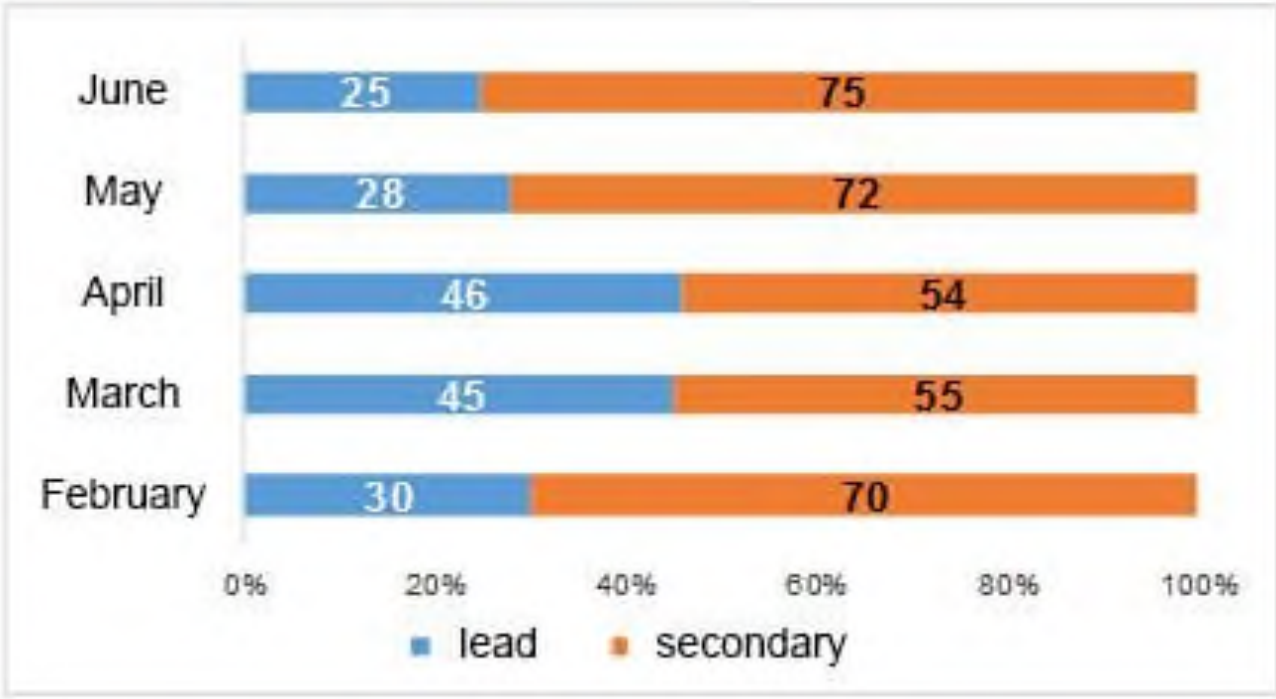

Fig. 3. Dynamics of publications by the role of references to the search object for the period February-June 2020 (in \% of the total number of messages per month).

The leading genre in which the work of the ministry was covered was undoubtedly news during the active period of distance learning; the growth of analytical publications was recorded in June, which indicates an awareness and understanding of the process of distance learning, its advantages, costs and problems (Fig. 4).

\begin{tabular}{|c|c|c|c|c|c|}
\hline Interview & $0,5 \quad 0,4$ & 1 & \multicolumn{2}{|c|}{1,5} & 1 \\
\hline Legislation & 1 & 1 & \multicolumn{2}{|r|}{1,5} & 1,3 \\
\hline Other & 4,5 & 2,6 & 4 & 4 & 5.7 \\
\hline Analitics & 20 & 16 & 17 & 21 & 26 \\
\hline News & 74 & 80 & \multicolumn{2}{|l|}{77} & 66 \\
\hline \multicolumn{3}{|c|}{ " February = March " April } & \multicolumn{2}{|c|}{ " May I June } & \\
\hline
\end{tabular}

Fig. 4. Distribution of publications by genre (February-June 2020, in \% of the total number of posts per month).

All five months of examination proved the leading role of the "Science and Education" and "Government" headings, which logically reflects the activities of the Ministry of Science and Higher Education. In March, there was an increase in topics related to health and medicine, while in April social issues outstripped health topics.

The tonality of media content demonstrated a decrease in positive content, starting with the crisis event - the announcement of the distance learning (DL) in March. Negative 
explosions occurred against the background of making decisions on the distant examinations and USE (Fig. 5).

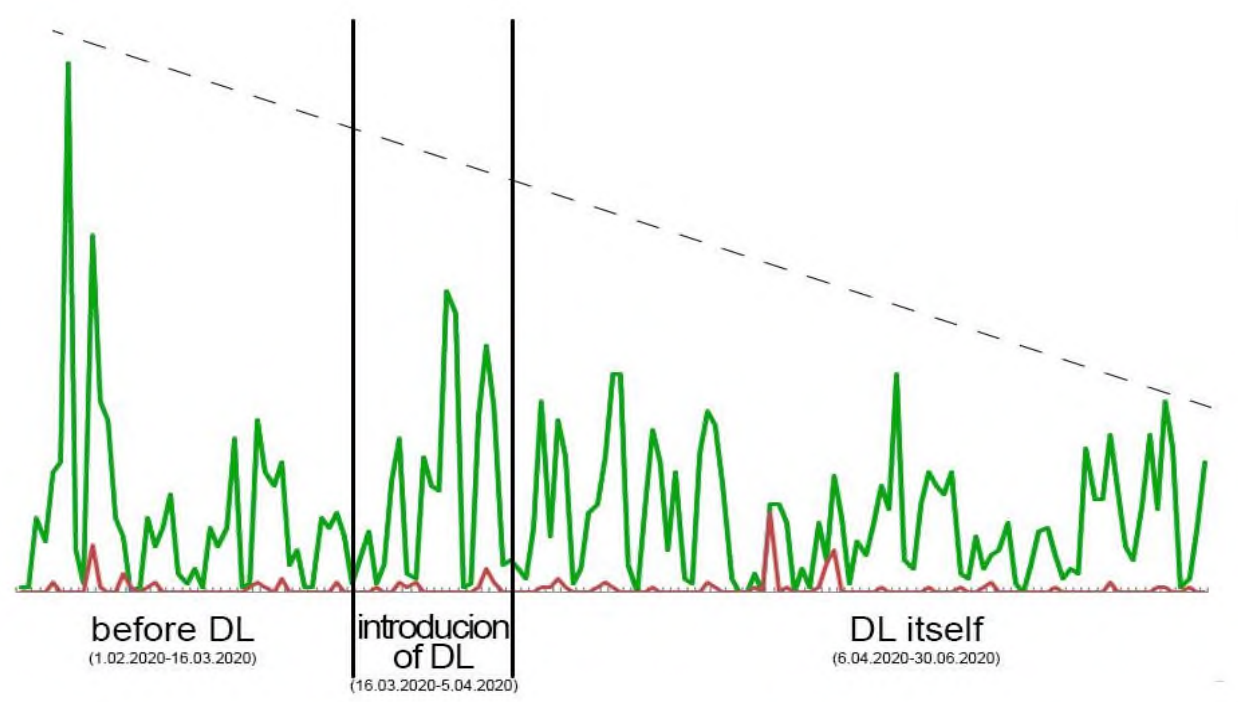

Fig. 5. Positive and negative tonality of references to the search object "Ministry of Science and Higher Education" for the period February-May 2020 (in units).

As the generated tag clouds show, at the very beginning of the coronavirus pandemic and, accordingly, even before the announcement of the transition to the distance learning, search queries were associated with the scientific life of the university ("science", "scientific" "university"), not yet discussions of distance conditions of educational work prevailed, but the main tag of March is associated with the introduction of university distance learning: one can say more - during this period, a semantic breakdown in educational discourse occurred "science" and the "university" itself left it. In April, this trend was confirmed [10-14]. In May, "university" returns to the semantic field of the university, the semantic structure is filled with the tags "education", "exam", "Unified State Exam", "student", "educational", and the word "remote" fades into the background.

\section{Conclusion}

The spread of the coronavirus epidemic led to profound social changes and led to the transformation of social institutions, and the institute of higher education was no exception. Online education was a crisis situation for a number of social groups - educators, students and members of their families, which could provoke stressful situations, lead to the loss of the most important tasks of traditional education: the formation of a value-semantic structure, a system of knowledge, views and ideas among young people [3].

Our research conclusions are that the period of the onset of the crisis and, accordingly, the associated fear - in our case, the introduction of distance learning - takes about three weeks to comprehend. During these 22 days of crisis - from March 16 to April 6 - there was a different reaction from other periods of society to the distance education, reflected in the media agenda. We believe that the reaction of society to the crisis phenomenon in the media space depends on a number of factors: urbanistic - the social overcrowding of megacities leads to an increase in the perception of the crisis and an increase in fear among the population; density of social contacts, which is also more evident in cities; media suspicion 
(increases in territories with a large Internet presence and Internet coverage); maturity (this is especially evident in the student environment). The identified adaptation period - from the beginning of a crisis event to the moment of its interiorization - can be analyzed both within the framework of medicine and psychology, and sociology. From our point of view, society gets used to the crisis after a fairly short period of time - 20-24 days, adapting to it and forming ways out of it. In our case, the attempt to return to the comfort zone - to the situation before the introduction of the distance learning - explains the formation and development of social moods of covid-dissidence and distant-learning-dissidence, the desire to return to traditional types of social interaction and habitual social contacts.

Media analytics of the work of the Ministry of Science and Higher Education identified a number of interesting trends. Firstly, the problem fields, formulated by distance education were identified. Among them one should mention the desire among students not to pay the full cost of educating carried out online; the risk of losing foreign students enrolled; distant mode of taking exams, including state exams and graduation qualification works defense; the USE in the context of social distancing; organization of admission campaigns to universities in new conditions using digital technologies.

Secondly, the introduction of distance education has led to a change in the system of interaction between the teacher and the student. Rapid and often ineffective adaptation to new educational practices by the administration of universities, teaching staff, students and their parents took place.

Thirdly, the pandemic not only posed the problems associated with the "forced" introduction of distance learning on a federal scale, but also provided a unique opportunity for the higher education system to self-diagnose its functioning in a crisis and threat environment.

Noting the costs of the distance education, it is necessary, on the one hand, to understand that there were no alternatives to the transition to the distance mode at the time of its introduction. The transition to a distance learning "off the wheels" was associated with costs, especially at the initial stage, and different universities coped with this in different ways. But the discussion about the digitalization of the educational process must be continued, since the quality of university education directly relates to the stability of the economy in the near future. At the same time, one must be aware that the timely transition of universities to online mode saved thousands of students and teachers from the virus, that is, the distance education to some extent protected society as a whole from the epidemic.

\section{References}

1. K. Hack, Rethinking Higher Education for a post-pandemic world (2020) URL: https://www.advance-he.ac.uk/news-and-views/rethinking-higher-education-postpandemic-world. (Last accessed 11.01.2021)

2. S. Hall, Vopros kul'turnoy identichnosti, Khudozhestvennaya zhizn', 77-78 (2015) http://xz.gif.ru/numbers/77-78/hall// (Last accessed 11.01.2021)

3. V. V. Kasyanov, V. V. Kovalev, S. I. Samygin, Universitetov ne dolzhno byt' mnogo: klassicheskiy universitet $\mathrm{v}$ strukture reformiruyemoy sistemy vysshego obrazovaniya Rossii, Gumanitarnyye, sotsial'no-ekonomicheskiye i obshchestvennyye nauki, 2, 17-20 (2017)

4. Ye. V. Pereverzev, Ye. A. Kozhemyakin, Politicheskiy diskurs: mnogoparametral'naya model', Vestnik Voronezhskogo gosudarstvennogo universiteta, 2, 74-79 (2008)

5. Obshchestvennyy sovet pri Minobrnauki Rossii obsudil uroki pandemii (2020) https://minobrnauki.gov.ru/ru/press-center/card/?id_4=2777 (Last accessed 15.01.2021) 
6. Dzh. Shapiro, Transatlanticheskiye otnosheniya i koronavirus, Rossiya v global'noy politike. (2020) https://globalaffairs.ru/articles/transatlantica-i-koronavirus/ (Last accessed 15.01.2021)

7. Tekhnologii analiza SMI i sotssetey https://www.mlg.ru/about/technologies/\#mediaindex (Last accessed 17.01.2021)

8. E. Toffler, Shok budushchego : per.s angl. Moskva: ACT., 557 (2002)

9. V. Vakhshtayn Pandemiya, strakh, solidarnost', Rossiya v global'noy politike, 3 (2020) https://globalaffairs.ru/articles/pandemiya-strah-solidarnost/ (Last accessed 17.01.2021)

10. I. Wallerstein, Konets znakomogo mira: sotsiologiya XXI veka. Moskva: Logos, 368 (2004)

11. O. Weaver, B. Buzan, M. Kelstrup, P. Lemaitre, Identity, Migration and the New Security Agenda in Europe, 221 (London, Pinter Publishers Ltd., 1993)

12. S. Chernyi, V. Budnik, "Methods for optimizing solutions when considering group arguments by team of experts" (2017) 10.1063/1.5009873.

13. S. Chernyi, N. Logunova, L. Aleksahina, "Institutional and organizational aspects of regional marine transport system strategic development", 2017 International Conference "Quality Management,Transport and Information Security, Information Technologies" (IT\&QM\&IS) (2017) 10.1109/itmqis.2017.8085780

14. V. Reshnyak, S. Sokolov, S. Chernyi, T. Storchak, Y. Tihomirov, "System aspect course of creation of information and analytical system of environmental monitoring and control", IOP Conference Series: Earth and Environmental Science, 87(4), 042017 (2017) $10.1088 / 1755-1315 / 87 / 4 / 042017$ 